УДК 339.543

Г.А. ТІХОСОВА, О.М. ВЕРБИЦЬКИЙ, Є.О. КАЛІНСЬКИЙ

Херсонський начіональний технічний університет

\title{
ТОВАРОЗНАВЧА ХАРАКТЕРИСТИКА ІДЕНТИФІКАЦІЙНИХ ОЗНАК КЕРАМІЧНОГО ПОСУДУ З МЕТОЮ КЛАСИФІКАЦІЇ ВІДПОВІДНО ДО УКТЗЕД
}

\author{
Г.А. ТИХОСОВА, А.Н. ВЕРБИЦКИЙ, Е.А. КАЛИНСКИЙ \\ Херсонский национальний технический университет \\ ТОВАРОВЕДНАЯ ХАРАКТЕРИСТИКА ИДЕНТИФИКАЦИОННЫХ \\ ПРИЗНАКОВ КЕРАМИЧЕСКОЙ ПОСУДЫ С ЦЕЛЬЮ \\ КЛАССИФИКАЦИИ ПО УКТВЭД
}

\author{
G. TIHOSOVA, A. VERBITSKY, E. KALINSKY \\ Kherson National Technical University \\ TRADE CHARACTERISTICS OF IDENTIFICATION \\ CHARACTERISTICS OF CERAMIC CABINETS FOR THE \\ CLASSIFICATION OF UCGFEA
}

https://doi.org/10.36910/6775-2310-5283-2019-12-22

Мета. Проведення аналізу сучасного стану нормативної документації щзодо класифікації керамічних товарів згідно з УКТЗЕД, ефективності застосування митними органами иих норм при вирішені спірних питань класифікації товарів та розроблення пропозицій щодо удосконалення класифікації циих видів товарів.

Методика. При дослідженнях використовували нормативно-правові та законодавчі акти, дані відкритих джерел. Застосовувалися наукові методи пізнання та аналітичні методи: систематизація, ідентифікація, узагальнення та класифікація.

Результати. В статті розглянуто ряд питань стосовно товарознавчої характеристики керамічного посуду та визначення ідентифікачійних ознак керамічного посуду з метою класифікаиії відповідно до Української класифікації товарів зовнішньоекономічної діяльності (УКТЗЕД). Недостовірне декларування керамічного посуду набуває особливої гостроти, оскільки зростає кількість випадків, коли декларанти заявляють посуд з фарфору як посуд з фаянсу, що має нижчу вартість $i$, відповідно, ставку імпортного мита. Крім цього, на різновиди керамічного посуду в УКТЗЕД встановлені різні ставки ввізних мит. Розглянувши розподіл експорту та імпорту по країнах, було визначено, щзо експортується в кількісному відношенні більше посуду з фарфору, а імпортується у багато разів більше посуду, виготовленого з інших видів кераміки. Зазначено, що незважаючи на широкий спектр способів, і методів ідентифікаціі товарів, митними експертами дуже часто приймаються невірні класифікаційні рімення. Ефективність застосування митними органами заходів тарифного та нетарифного регулювання щодо учасників ЗЕД знаходиться в прямій залежності від того, наскільки повно і точно вирімені питання класифікащії товарів. Тому учасник ЗЕД повинен правильно описувати товар в 31 графі та заявляти його код в 33 графі МД, а органи доходів $і$ зборів в свою чергу повинні ретельно здійснювати контроль достовірності заявленого коду. 
Наукова новизна отриманих результатів полягає у трунтовному аналізі основних положень нормативно-правових актів $з$ питань класифікації та митної вартості керамічних товарів, визначенні проблемних аспектів та їх сутності.

Практична значимість полягає у виявленні проблемних аспектів правових норм щзодо митної вартості товарів з кераміки, які можуть бути враховані під час розробки нормативно-правових актів стосовно визначення й контролю митної вартості товарів, а також у практичній роботі митних органів.

Ключові слова: товарна номенклатура, УКТЗЕД, класифікаційні рімення, керамічний nocyd

Постановка проблеми у загальному вигляді і її зв'язок 3 важливими науковими та практичними завданнями. Останнім часом недостовірне декларування керамічного посуду набуває особливої гостроти, оскільки зростає кількість випадків, коли декларанти заявляють посуд 3 фарфору як посуд з фаянсу, що має більш низьку вартість і ставку імпортного мита. Крім цього, на різновиди керамічного посуду в Українській класифікації товарів зовнішньоекономічної діяльності (УКТЗЕД) встановлені різні ставки ввізних мит [1-3]. Саме тому правильна товарознавча оцінка даних товарів згідно 3 УКТЗЕД $\epsilon$ актуальною. В свою чергу, авторами у даній роботі зроблена спроба застосувати товарознавчий підхід при класифікації цього виду продукції.

Аналіз останніх досліджень. Питання щодо митної експертизи досліджували у своїх роботах Дишлова В., Драганов В., Дусик А., Карпенко Г., Шевчук О. та інші. Вони зазначали, що зазвичай на митниці під час перевірки правильності класифікації або підтверджують код, який визначив декларант, або змінюють цей код. Зазвичай код змінюють на той, якому відповідає більша ставка мита, щоб збільшити розмір митних платежів. В умовах, коли тільки митниця є єдиним органом, який має право приймати рішення щодо класифікації товару i висновки будь-яких інших органів, підприємств чи окремих експертів мають довідковий характер, важливо щоб не було двозначностей при визначенні коду того чи іншого товару.

Цілі статті. Провести аналіз сучасного стану нормативної документації щодо класифікації керамічних товарів згідно з УКТЗЕД; визначити ефективність застосування митними органами цих нормативних норм при вирішені спірних питань класифікації товарів.

Для виконання поставлених цілей авторами застосовувалися аналітичні методи: систематизація, ідентифікація, узагальнення та класифікація.

Виклад основного матеріалу дослідження 3 повним обгрунтуванням отриманих наукових результатів. Останнім часом явно помітно кількісне 
збільшення як обсягів експорту з України (рис.1), так і обсягів імпорту в Україну керамічного посуду (рис.2). Це підтверджує актуальність і важливість теми даної статті.

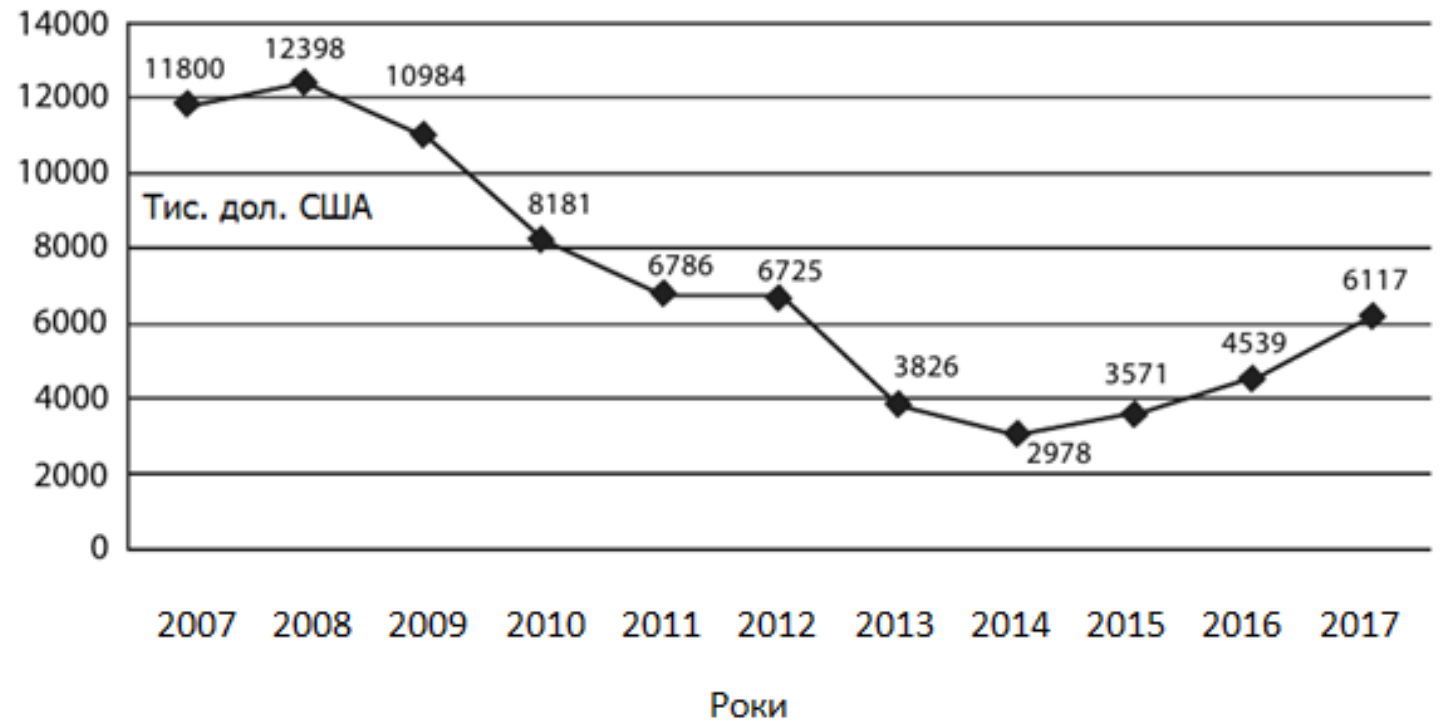

Рис. 1. Динаміка змін обсягів експорту кераміки з України

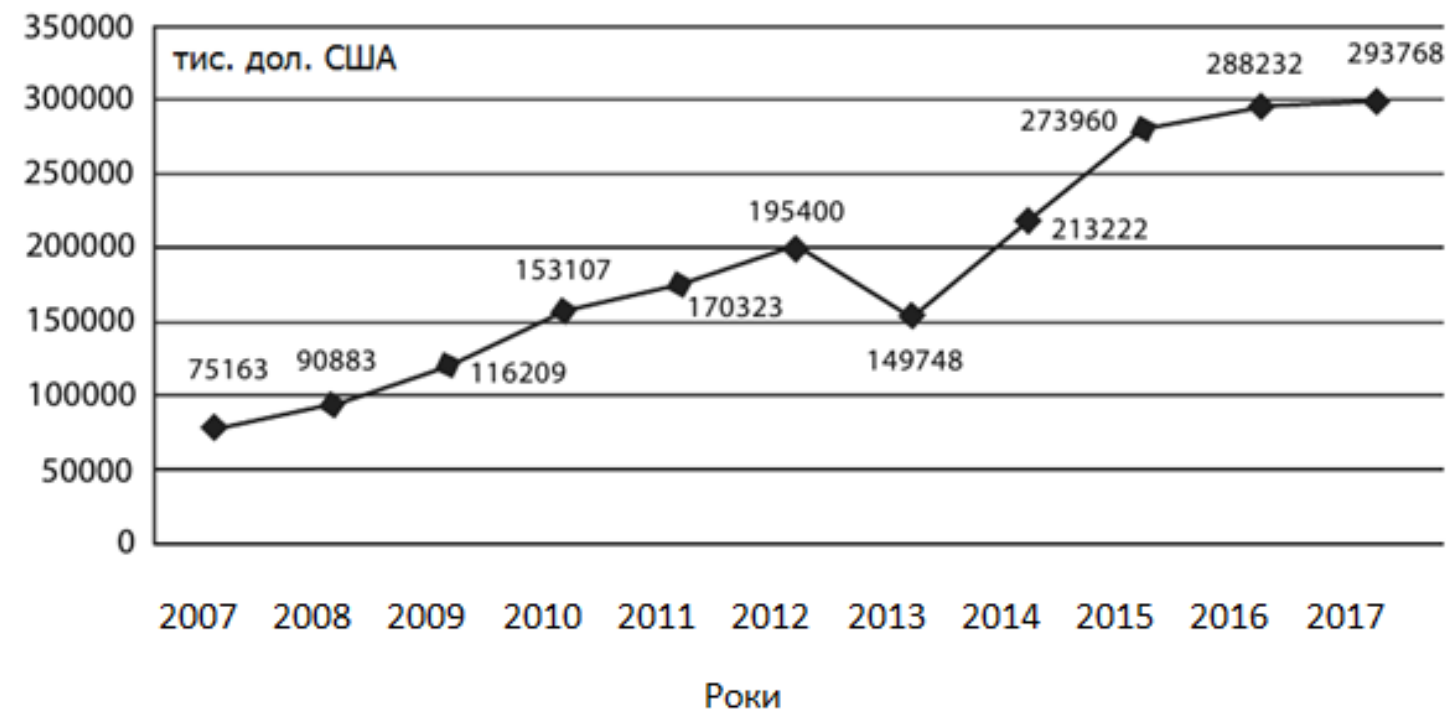

Рис. 2. Динаміка змін обсягів імпорту кераміки в Україну

Розглянувши динаміку змін обсягу експорту та імпорту за 2007-2017 рік, було виявлено, що імпортується в кількісному відношенні більше товарів, які виготовлені з кераміки, а значне зменшення експорту в 2008-2017 роках пов'язане 3 економічною кризою i конфліктом на сході України, де розташовані значні потужності з виробництва керамічних виробів [4].

Істотні обсяги експорту керамічного посуду з України припадають на Казахстан, а основним імпортером є Китай. 
Як відомо, згідно з прийнятими в Україні наказами та постановами $[5,6]$ та УКТЗЕД вироби з кераміки групуються за такими ознаками:

- походження;

- функціональне призначення;

- вид матеріалу, з якого виготовлено товар.

Як вже зазначалося раніше, одним із шляхів вирішення суперечок стосовно правильної класифікації товарів є застосування попередніх рішень [7]. Однак, на жаль, поки що їх кількість недостатня для унеможливлення усіх суперечок.

Виходячи 3 аналізу митної практики, учасники зовнішньоекономічної діяльності (ЗЕД) в деяких випадках при описі товару в 31 графі вантажної митної декларації (МД), не вказують важливу інформацію, необхідну для класифікації товарів відповідно до основних правил інтерпретації (ОПІ) УКТЗЕД 1, 2, 3, і товар помилково класифікують за ОПІ 4, в результаті чого товару присвоюється недостовірний код, ставка мита якого значно нижче ставки, що сплачується при достовірній класифікації товару. Це призводить до ухилення від сплати митних платежів і $є$ адміністративним правопорушенням.

Проаналізувавши матеріали судової практики, які є у відкритому доступі, були виявлені основні помилки при класифікації товарів за УКТЗЕД:

- недостатня інформація для ідентифікації товару, що міститься в графі 31 МД;

- невірне застосування ОПІ;

- незастосування приміток до розділів, груп, позицій і товарних категорій;

- ігнорування нормативно-правових актів, що уточнюють та регламентують класифікацію конкретних товарів;

- некомпетентність митних експертів при видачі висновку митного експерта про вид матеріалів, з яких виготовлений товар.

При розгляді судових справ про оскарження рішення митного органу про класифікацію товарів основним доказом позиції митниці $\epsilon$ експертний висновок, що містить інформацію, на підставі якої митні органи класифікували товар.

Основними методами ідентифікації керамічного посуду, що використовуються експертами в ході митної експертизи, є:

- органолептичний (визначається колір, звук, скол черепка і характер нанесення глазурі);

- фізико-хімічний (визначається коефіцієнт водопоглинання, твердість за шкалою Мосса);

- оптичний (проводиться аналіз структури матеріалу з використанням 
мікроскопів);

- рентгеноспектральний метод (проводиться ідентифікація елементного складу зразків на спектрометрі).

Але, незважаючи на широкий спектр способів і методів ідентифікації товарів, митними експертами дуже часто приймаються невірні класифікаційні рішення. Проаналізувавши судову практику, нам вдалося виявити основні причини цього.

По-перше, експертами не застосовуються поправки, які було прийнято у результаті змін у міжнародних торговельних стандартах. Товарні позиції 6907 (неглазуровані керамічні вироби) і 6908 (глазуровані керамічні вироби) було об'єднано у зв'язку з тим, що основні підпозиції в цих товарних позиціях стосуються товарів, які, по суті, більше не виробляються, і промисловість й торгівля більше не роблять розходження між неглазурованими i глазурованими керамічними виробами, водночас нові вироби дуже високим обсягом продаж класифікувалися за товарними підпозиціями 690790 та 6908 90 ("Інше") [8]. Крім того отримані результати не забезпечуються конкретними відомостями про використані експертами методи при визначенні коефіцієнта водопоглинання.

По-друге, найчастіше експерти роблять однозначний висновок про матеріал, 3 якого виготовлений товар, тільки на підставі критеріїв водопоглинання, але для достовірної ідентифікації цього недостатньо.

По-третє - експерти виявляють ознаки характерні не тільки для фарфору, на підставі яких роблять необгрунтовані висновки. Зокрема, у зразків посуду спірного товару визначають білий колір і просвічуваність органолептичними методами, хоча відповідно до ДСТУ 3889-99 «Вироби декоративні фарфорові і фаянсові. Загальні технічні умови» та ГОСТ 24768 "Изделия фарфоровые. Метод определения белизны" дані показники реєструються спектрофотометром - вимірювальним методом, що дозволяє отримати більш точні та об'єктивні результати. Такі дослідження вважаються отриманими шляхом поверхневого аналізу, без проведення відповідних вимірювальних досліджень з методологічними помилками [9 - 10].

Згідно з УКТЗЕД посуд з фарфору і керамічний посуд, крім посуду 3 фарфору для технічного використання, класифікуються в товарних позиціях 6911 і 6914. Проаналізувавши зміст даних товарних позицій, було з'ясовано, що товари, які класифікуються в них, підлягають оподаткуванню за різними ставками ввізного мита, що породжує ризикову ситуацію, яка виражається у можливій недостовірній заяві відомостей щодо виду кераміки 3 метою 
зменшення належних до сплати митних платежів.

Виходячи $з$ пояснень до групи 69 УКТЗЕД і приміток до підгрупи 14 «Інші керамічні вироби», а також використовуючи офіційні пояснення та стандарти [9-10], була складена таблиця розходжень ідентифікаційних ознак кераміки (табл. 1).

Таблиця 1

Ідентифікаційні ознаки кераміки

\begin{tabular}{|c|c|c|c|c|}
\hline Ознака & Фарфор & $\begin{array}{c}\text { Груба } \\
\text { кераміка }\end{array}$ & $\begin{array}{l}\text { Кам'яна } \\
\text { кераміка }\end{array}$ & $\begin{array}{c}\text { Фаянс } \\
\text { (тонка кераміка) }\end{array}$ \\
\hline Структура & $\begin{array}{l}\text { Щільна структура. } \\
\text { Відсутність пор, } \\
\text { пустот, раковин, } \\
\text { розшарувань і } \\
\text { включень }\end{array}$ & $\begin{array}{c}\text { Велика } \\
\text { неоднорідна } \\
\text { зернистість на } \\
\text { зламі черепка }\end{array}$ & $\begin{array}{c}\text { Щільна } \\
\text { дрібнозерниста } \\
\text { структура }\end{array}$ & $\begin{array}{c}\text { Високопориста, } \\
\text { пухка } \\
\text { дрібнозерниста } \\
\text { структура }\end{array}$ \\
\hline Колір черепка & Білий & $\begin{array}{l}\text { Червоний, } \\
\text { кремовий }\end{array}$ & $\begin{array}{c}\text { Сірий, } \\
\text { коричневий }\end{array}$ & Білий, кремовий \\
\hline Просвічуваність & $\begin{array}{c}\text { Напівпрозорий, } \\
\text { просвічується }\end{array}$ & \multicolumn{3}{|c|}{ Не просвічуються, непрозорі } \\
\hline $\begin{array}{l}\text { Прилипання до } \\
\text { язика }\end{array}$ & Не прилипає & \multicolumn{3}{|c|}{ На зламі прилипають до язика } \\
\hline $\begin{array}{l}\text { Стійкість до } \\
\text { вістря сталевого } \\
\text { предмета }\end{array}$ & Добре стійкий & Нестійкий & $\begin{array}{l}\text { Середня } \\
\text { стійкість }\end{array}$ & Нестійкий \\
\hline $\begin{array}{l}\text { Коефіцієнт } \\
\text { водопоглинання }\end{array}$ & Менше 0,2 \% & $8-10 \%$ & Близько $2 \%$ & 5 \% і більше \\
\hline Термічна стійкість & $\begin{array}{c}\text { Висока } \\
\text { термостійкість }\end{array}$ & \multicolumn{3}{|c|}{ Менш термостійкий, ніж фарфор } \\
\hline Характер звуку & $\begin{array}{c}\text { Високий ясний } \\
\text { дзвін }\end{array}$ & \multicolumn{3}{|c|}{ Глухий і низький звук } \\
\hline Водопроникність & $\begin{array}{c}\text { Практично } \\
\text { водонепроникні } \\
\text { навіть без глазурі }\end{array}$ & \multicolumn{3}{|c|}{ Водопроникні } \\
\hline
\end{tabular}

Згідно 3 поясненнями до УКТЗЕД найсуттєвішою ознакою для правильної класифікації спірного товару (керамічного посуду) між двома товарними позиціями $є$ вид матеріалу, з якого виготовлений спірний товар.

Найчастіше саме 3 цього приводу виникають суперечності між учасниками ЗЕД та органами доходів i зборів. Наприклад, виходячи 3 матеріалів справи № 0097760-06 ТОВ «Чистий світ-К» звернулося до Вищого адміністративного суду України із заявою до Київської регіональної митниці 
про визнання недійсним класифікаційного рішення митниці. На думку ТОВ «Чистий світ-К», дії митниці щодо зміни коду УКТЗЕД з 691200 на 691110, які спричинили збільшення ставки мита i, відповідно, нарахування додаткових митних платежів, $є$ незаконними, тому що результати судової експертизи підтверджують, що зразки товару виготовлені не з фарфору, а з напівфарфору, який входить в категорію «інших керамічних виробів».

В процесі судового розгляду додатково була проведена матеріалознавча експертиза, в ході якої з'ясувалося, що ввезений товар був виготовлений 3 напівфарфору і тому відноситься до товарної позиції 6914. На підставі цього суд задовольнив вимоги ТОВ «Чистий світ-К» і визнав незаконним рішення Київської регіональної митниці.

Висновки та перспективи подальших досліджень. Виходячи 3 вищевикладеного, можна зробити висновок, що ефективність застосування митними органами заходів тарифного та нетарифного регулювання щодо учасників ЗЕД знаходиться в прямій залежності від того, наскільки повно і точно вирішені питання класифікації товарів. Тому учасник ЗЕД повинен правильно описувати товар в 31 графі і заявляти його код в 33 графі МД, а органи доходів і зборів в свою чергу повинні ретельно здійснювати контроль достовірності заявленого коду.

\section{Список використаних джерел}

1. Про Митний тариф України [Текст] : Закон України : прийнятий Верх. Радою України 19 вересня 2013 р. // Відомості Верховної Ради (ВВР). - 2014. - № 20-21. - ст.740.

2. Про Митний тариф України [Текст] : додаток до Закону України № 584-VII : прийнятий Верх. Радою Укр. 19 вересня 2013 р. // Відомості Верховної Ради (ВВР). - 2018. - № 49. - ст.399.

3. Митний кодекс України [Текст] : кодекс законів України : прийнятий Верх. Радою України 13 березня 2012 р. // Відомості Верховної Ради України (ВВР), 2012. - № 44-45, № 46-47, №8. - ст.552.

4. Економічна статистика зовнішньоекономічної діяльності [Електронний peсурс]. - Режим доступу : http://www.ukrstat.gov.ua/operativ/menu/menu_u/zed.htm.

5. Про приєднання України до Міжнародної конвенції про Гармонізовану систему опису та кодування товарів : Указ Президента України від 17 травня 2002 р. [Електронний ресурс]. - Режим доступу : https://www.president.gov.ua/documents/4662002101.

6. Про затвердження Порядку ведення Української класифікації товарів зовнішньоекономічної діяльності та визнання такими, що втратили чинність, деяких постанов Кабінету Міністрів України : Постанова Кабінету Міністрів України від 21 травня 2012 p. № 428 [Електронний ресурс]. - Режим доступу : https://zakon.rada.gov.ua/laws/show/428-2012-п

7. Калінський Є.О. Особливості застосування попередніх рішень при класифікації товарів зовнішньоекономічної діяльності / Є.О Калінський, Жаник Казимір // 
Шляхи вдосконалення системи технічного регулювання в Україні та світі: матеріали Міжнародної науково-практичної конференції, (12-14 вересня 2018 р.), м. Херсон. Херсон: вид-во ФОП Вишемирський В.С., 2018. - С. 61-63

8. Мельник А. УКТ ЗЕД версії 2017 р.: зміни в класифікації / А. Мельник // Вісник. Офіційно про податки. - 2017. - №45. - С. 12-13.

9. Вироби декоративні фарфорові і фаянсові. Загальні технічні умови : ДСТУ 3889-99 [Чинний від 2000-01-01]. - К.: Держстандарт України, 1999. - III, 18 с. (Державний стандарт України).

10. Изделия фарфоровые. Метод определения белизны : ГОСТ 24768 - 2000 [Действует с 2001-09-01]. - Минск: Межгосударственный совет по стандартизации, метрологии и сертификации, 2000. - II, 16 с. - (Межгосударственный стандарт).

Цель. Провести анализ современного состояния нормативной документации по классификаџии керамических товаров согласно УКТВЭД; определить эффективность применения таможенными органами этих норм при решении спорных вопросов классификации товаров из керамики и разработка предложений по совершенствованию классификации этих видов товаров.

Методика. При исследованиях использовали нормативно правовые и законодательные акты, данные открытых источников. Применялись научные методы познания и аналитические методы: систематизаџия, идентификащия, обобщение и классификаџия.

Результаты. В статье рассмотрен ряд вопросов по товароведной характеристике керамической посуды и определения идентификационных признаков керамической посуды с целью классификаџии по Украинской классификащии товаров внешнеэкономической деятельности (УКТВЭД).

Недостоверное декларирование керамической посуды приобретает особую остроту, поскольку растет количество случаев, когда декларанты заявляют посуду из фарфора как посуду из фаянса, которая имеет более низкую стоимость и ставку ввозной пошлинь. Кроме этого, на всевозможные разновидности керамической посуды в УКТВЭД установлены различные ставки ввозных пошлин. Рассмотрев распределение экспорта и импорта по странам было определено, что экспортируется в количественном отношении больше посуды из фарфора, а импортируется во много раз больше посуды, изготовленной из керамики. Отмечено, что несмотря на широкий спектр способов и методов идентификации товаров, таможенными экспертами очень часто принимаются неверные классификационные решения.

Эфррективность применения таможенныли органами мер тарифного и нетарифного регулирования в отношении участников ВЭД находится в прямой зависимости от того, насколько полно и точно решены вопросы классификации товаров. Поэтому участник ВЭД должен правильно описывать товар в 31 графе и заявлять его код в 33 графе МД, а органы доходов и сборов в свою очередь должны тмательно осуществлять контроль достоверности заявленного кода.

Научная новизна полученных результатов заключается, в основательном анализе основных положений нормативно-правовых актов по вопросам классификации и таможенной стоимости керамических товаров, определении проблемных аспектов и их сущности. 
Практическая значимость заключается в выявлении проблемных аспектов правовых норм по таможенной стоимости товаров из керамики, которые могут быть учтены при разработке нормативно-правовых актов по определению и контролю таможенной стоимости товаров, а также в практической работе таможенных органов.

Ключевые слова: товарная номенклатура, УКТВЭД, классификационные решения, керамическая посуда

Purpose. Purpose is to analyzing of the current state of regulatory documentation about the classification of ceramic goods according to UCGFEA, the effectiveness of the application of these norms by customs authorities in solving controversial issues of product classification and the development of proposals for improving the classification of these types of goods.

Methodology. During the researches we used regulatory and legislative acts, data from open sources. The scientific methods of knowledge and the analytical methods were used is: systematization, identification, generalization and classification.

Findings. The number of questions about commodity descriptions and identification features of ceramic tableware for classification according to Ukrainian classification of goods for foreign economic activity are discussed in the article.

Unreliable declaring of ceramic tableware becomes especially important, because it increases that the number of cases in which declarants declare porcelain dishes as earthenware dishes has a lower cost and import duty rate. In addition, the UCGFEA classifier installed on all sorts of ceramic tableware different rates of import duties. Considering the distribution of exports and imports from countries, it was determined that quantitatively exported more porcelain tableware, and much more ceramic tableware is imported. It was noted that despite a wide range of the ways and methods for identifying the trade goods, customs experts often make the wrong classification decisions.

The effectiveness of the application by customs authorities of measures of tariff and nontariff regulation with respect to participants in foreign trade is directly dependent on how fully and accurately the classification of commodity is resolved. Therefore, a participant in foreign trade must correctly describe the commodities in 31 column and declare their code in 33 column of the customs declaration. Customs officers, in turn, must carefully control the accuracy of the declared code.

Originality. The scientific novelty of the obtained results consists in a thorough analysis of the regulatory legal acts on the classification and customs value of ceramic goods, the definition of problematic aspects and their essence.

The practical value. The practical significance lies in identifying problematic aspects of the legal norms on the customs value of ceramic goods, which can be taken into account in the development of regulatory acts on the definition and control of the customs value of goods, as well as in the practical work of the customs authorities.

Keywords: commodity nomenclature, UCGFEA, classification solutions, pottery.

Стаття рекомендована до друку

д.т.н., професором Чкурсіною Л.А. Дата надходження в редакиію 12.02.2019 p. 